\title{
Environmental safety of construction processes in the Republic of Belarus
}

\author{
Alena Kisel $^{1, *}$ and Liudmila Sryukina ${ }^{1}$ \\ ${ }^{1}$ Brest State Technical University, 224017, Moskovskaya 267, Brest, Belarus
}

\begin{abstract}
In creating or changing real estate property - buildings and structures - a rational use of natural resources and environmental safety of construction activities which result from the actions of all participants at each stage of the construction project implementation are becoming more and more relevant. A construction project should be considered as a subject of investment and construction activities: from its concept to its operation. The theoretical level of environmental safety is laid down at the stage of pre-project studies and design. During the development of the construction site and the execution of construction and installation works, the actual environmental safety is formed. It must be maintained in the future by proper organization of the object's operation. The basis for the development of environmental safety of investment and construction processes is the legal framework and the introduction of environmental management in the activities of participants in the investment and construction cycle. It is possible to achievement of results only under condition of continuous performance of all functions of environmental management by each of the participants in investment and construction activities. These functions must be integrated into the organizational structure of construction organizations, which will allow you to correctly distribute environmental functions within all divisions.
\end{abstract}

Keywords: investment and construction activities, environmental safety, environmental management, management functions.

\section{Introduction}

The object of this research is the processes of forming environmental safety of a project at each stage of investment and construction activities: at the stage of developing a concept of creating or changing a real estate object, choosing a construction site, designing, preparing construction production, performing construction and installation works.

In the investment and construction process, a rational use of natural resources and environmental safety of construction activities which result from the actions of participants at each stage of the construction project implementation are becoming more and more relevant. But the foundation of environmental safety is at the early stages of developing a concept of a construction project and choosing a site for construction. The quality of decisions made at this

* Corresponding author: eleniva2006@mail.ru 
stage regarding a choice of materials, structures, engineering and technological equipment depends not only on the initial capital investment, but also on further operating costs, including those related to ensuring a required level of environmental safety of the project throughout its life cycle and creating a sustainable environment for activities.

In creating or changing a real estate property, a large number of participants are involved, each of whom has its own interest in this activity. At the same time, all stages of the construction project must be environmentally friendly and contribute to the creation of a safe facility. To achieve this goal, it is necessary to implement environmental management in the activities of participants in the investment and construction cycle.

Major research in this area is currently focused on integrating the Life Cycle Sustainability Assessment (LCSA) with the building design process and Building Information Modelling (BIM) [1-6], as well as on sustainability issues from a building management perspective.

Key management approaches in construction organizations to move towards sustainable development include: sustainable procurement, integrated project delivery (IPD), environmental management system, building sustainability assessment systems, and postoccupancy management [7].

Integrated project delivery (IPD) is an approach that brings together the capacities and interests of all stakeholders in the investment cycle into a single process to reduce costs and improve efficiency at all stages of planning, design and construction.

Various green rating systems are being developed to assess the sustainability of construction projects: LEED (Leadership in Energy and Environmental Design), BREEAM (Building Research Establishment Assessment Method), CASBEE (Comprehensive Assessment System for Building Environmental Efficiency), Green Star NZ and others. Further research in this area is likely to focus on economic and institutional factors [8] and integration of LCA and LEED methodology [9].

Researchers are working on the environmental safety problems of individual stages of the investment cycle. For example, causal relations of adverse environmental impacts of construction sites are investigated [10], indicators for real-time monitoring of environmental pollutants in construction for the purpose of system planning of work by construction companies and management of pollutants at construction sites are defined [11], various directions of development and improvement of green construction projects are considered: costs, schedule, safety, rework, productivity, risk assessment and mitigation measures, risk management, and leadership [12].

The purpose of this study is to identify the tasks for environmental management at all stages of the investment project in the construction and distribution of environmental responsibilities between offices of the organizations participating in the investmentbuilding cycle to promote environmental safety.

To achieve this goal, it is planned to solve the following tasks: assessment of the impact of individual stages of investment and construction activities on the environment; characteristics of the legal framework for environmental construction in the Republic of Belarus; development of special functions within the framework of environmental management for divisions of organizations participating in the implementation of an investment project in construction.

The study used empirical methods - observation and comparison, theoretical research methods - analysis and synthesis, and mental modeling.

\section{Impact of stages of investment and construction activities on the environment}

In the existing practice of analysis in the Republic of Belarus, each of the stages of creating (changing) a real estate object is investigated independently, since it is assigned to a separate performer. 
Mutual influence is poorly monitored, which means that the strength of management decisions is weakened. This is due to the fact that in general, considering a construction object as a subject of investment and construction activities is very rare. A search for relationships would ensure alternative options for optimizing possible negative impacts on the environment, and would reduce risks throughout an investment and construction cycle as a whole. If all participants in investment and construction processes were guided by environmental management procedures, this would become a basis for formainf an environmental safety management system for finished construction projects. Let's look at the features of each of the following stages:

- Creating a project concept and development of project documentation,

- Site selection for construction,

- Preparation of construction production,

- Construction and installation works.

The concept is formed at the pre-project (pre-investment) stage of the property's life cycle. At this stage, the investment justification is developed, which determines a necessity, technical and economic feasibility of investing in the construction, reconstruction, and restoration of a facility, as well as the environmental impact assessment and calculation of environmental consequences of construction and operational activities. At this stage, the ecological potential of the project is laid for the entire future period of its existence, so the following are extremely important::

- Conscious and competent approach,

- Variant study of architectural solutions, engineering and technological equipment of the project,

- Economic assessment of investment efficiency, taking into account an initial capital investment and upcoming operating costs over the entire life cycle of the project (Table 1).

The main role at this stage belongs to the customer (owner) who makes fundamental decisions on feasibility of developing options for space-planning and structural solutions of the project, as well as solutions related to engineering and technological equipment [13]. It is important for them to understand and accept the concept of "sustainable development" of sustainable planning, designed for a long period of time and aimed at achieving the best result both from the point of view of the owner and from the point of view of the state of the environment, i.e., to create a sustainable environment for activities. Creating a sustainable business environment implies:

- Reducing investment in energy, raw materials, and water while increasing the cost of acquiring knowledge and skills,

- Optimizing a life span of the facility,

- Creating premises with better consumer properties (better living environment),

- Reducing emissions and waste during construction and operation of the facility,

- Creating products with improved environmental parameters (for industrial and engineering infrastructure objects),

- Increasing satisfaction of buyers of products, works, services or users of the facility (for example, tenants),

- Increasing the property owner's income.

The effectiveness of implementation of the first stage is undoubtedly affected by the quality of project documentation development, including technical solutions and measures for rational use of natural resources and prevention of environmental pollution $[14,15]$. 
Table 1. Formation of an environmental potential of a project at the stage of the project concept and design development.

\begin{tabular}{|c|c|c|}
\hline \multicolumn{3}{|c|}{ Formation of a project concept } \\
\hline \multicolumn{3}{|c|}{ Spheres of decision-making } \\
\hline $\begin{array}{l}\text { Architectural and planning } \\
\text { solutions }\end{array}$ & $\begin{array}{l}\text { Engineering infrastructure of } \\
\text { the project }\end{array}$ & $\begin{array}{l}\text { Selection of materials, } \\
\text { structures, products, and } \\
\text { technological equipment }\end{array}$ \\
\hline \multicolumn{3}{|c|}{ Emerging potential } \\
\hline \multicolumn{3}{|c|}{$\begin{array}{l}\text { - heat engineering characteristics (energy efficiency), } \\
\text { - use of natural renewable sources, } \\
\text { - durability, commercial use options, } \\
\text { - ability to redevelop and recycle the materials used }\end{array}$} \\
\hline \multicolumn{3}{|c|}{ Optimization of the resources to be consumed in the future } \\
\hline
\end{tabular}

According to the results of the State expertise of project documentation in Belarus, the following typical violations are identified:

- Unsubstantiated or unreliable data on parameters of the project's impact on the environment,

- Incomplete description of the current state of environmental components (before the construction of a project),

- Unreliable or incomplete information on characteristics and condition of green spaces, the number of preserved and removed vegetation; lack of compensatory measures,

- Lack of measures aimed at soil protection,

- Lack of a comprehensive solution to the issues of neutralization, use and disposal of wastes, including the construction ones,

- Non-compliance of the project's location with the requirements of the established regime of protection and use of the territory, its functional purpose.

The result of the evaluation of the first stage (pre-project stage, design) could be more effective if the choice of a site for construction is more deliberate (Table 2).

Table 2. Influence of the construction site selection process.

\begin{tabular}{|l|l|l|l|l|}
\hline \multicolumn{5}{|c|}{ Selection of a construction site. } \\
\hline \multicolumn{5}{|c|}{ Spheres of decision-making } \\
\hline $\begin{array}{l}\text { A necessity to } \\
\text { withdraw } \\
\text { agricultural land } \\
\text { from circulation }\end{array}$ & $\begin{array}{l}\text { A necessity to } \\
\text { withdraw } \\
\text { territories of the } \\
\text { forest fund }\end{array}$ & $\begin{array}{l}\text { A necessity to } \\
\text { use land near } \\
\text { water protection } \\
\text { zones }\end{array}$ & $\begin{array}{l}\text { A necessity to } \\
\text { use land for } \\
\text { recreation areas } \\
\text { in localities }\end{array}$ & $\begin{array}{l}\text { A necessity to } \\
\text { destroy the } \\
\text { habitat of } \\
\text { birds and } \\
\text { animals }\end{array}$ \\
\hline \multicolumn{5}{|c|}{ Result of decision making } \\
\hline $\begin{array}{l}\text { Search for new } \\
\text { places to grow crops, } \\
\text { loss of investment in } \\
\text { the development of } \\
\text { the territory }\end{array}$ & $\begin{array}{l}\text { Deforestation, } \\
\text { ecosystem } \\
\text { disruption }\end{array}$ & $\begin{array}{l}\text { Increasing risk } \\
\text { of pollution of } \\
\text { water and the } \\
\text { adjacent } \\
\text { territories }\end{array}$ & $\begin{array}{l}\text { Destruction of } \\
\text { parks, reduction } \\
\text { of green areas in } \\
\text { cities }\end{array}$ & $\begin{array}{l}\text { Death, } \\
\text { population } \\
\text { decline }\end{array}$ \\
\hline
\end{tabular}

Location of a construction project significantly affects not only its profitability during its operation and sale cost, but also the environmental friendliness of the construction process and preparation for it (Table 3). 
Table 3. Impact of preparation of construction industry.

\begin{tabular}{|c|c|c|}
\hline \multicolumn{3}{|c|}{ Preparation of construction industry } \\
\hline \multicolumn{3}{|c|}{ Spheres of decision-making } \\
\hline $\begin{array}{l}\text { Choice of production } \\
\text { technology }\end{array}$ & Planning of logistics processes & Designing a construction site \\
\hline \multicolumn{3}{|c|}{ Result of decision making } \\
\hline $\begin{array}{l}\text { Level of noise, dust, waste, } \\
\text { operating time of onstruction } \\
\text { machinery and equipment }\end{array}$ & $\begin{array}{l}\text { Level of waste materials, } \\
\text { organizational downtime, } \\
\text { percentage of defects }\end{array}$ & $\begin{array}{l}\text { Groundwater degradation, } \\
\text { landscape change, soil } \\
\text { erosion, loss of trees, shrubs, } \\
\text { garbage and its sorting }\end{array}$ \\
\hline
\end{tabular}

Good quality of preparation for construction production in order to reduce environmental impacts will allow reducing environmental risks at the next stage - the stage of work production (Table 4).

Table 4. Impact of stage of work production.

\begin{tabular}{|c|c|c|c|}
\hline \multicolumn{4}{|c|}{ Construction works during new construction, repair, reconstruction } \\
\hline \multicolumn{4}{|c|}{ Spheres of decision-making } \\
\hline $\begin{array}{c}\text { System of work } \\
\text { organization, } \\
\text { production practices }\end{array}$ & $\begin{array}{l}\text { Construction waste } \\
\text { management system }\end{array}$ & $\begin{array}{l}\text { Upgrading of } \\
\text { machinery and } \\
\text { transport }\end{array}$ & $\begin{array}{c}\text { Technological } \\
\text { discipline }\end{array}$ \\
\hline \multicolumn{4}{|c|}{ Result of decision making } \\
\hline $\begin{array}{l}\text { *level of resources use } \\
\text { *maintenance of } \\
\text { construction sites in } \\
\text { accordance with } \\
\text { regulations } \\
\text { *unjustified costs for } \\
\text { sites maintenance } \\
\text { *unjustified loss of } \\
\text { materials } \\
\text { *implementation of } \\
\text { sanitary standards for } \\
\text { household areas } \\
\text { *conditions for } \\
\text { materials storage }\end{array}$ & $\begin{array}{l}\text { *the amount of waste } \\
\text { *compliance with the } \\
\text { standard for the } \\
\text { volume of } \\
\text { construction waste } \\
\text { * garbage sorting } \\
\text { *handling waste that } \\
\text { exceeds the norm }\end{array}$ & $\begin{array}{l}\text { *level of fuel and } \\
\text { energy consumed } \\
* \text { CO2 emissions } \\
\text { *repair costs } \\
\text { *downtime } \\
\text { *use of the working } \\
\text { time fund }\end{array}$ & $\begin{array}{l}\text { *compliance with } \\
\text { waste levels } \\
\text { *level of waste } \\
\text { *compliance with } \\
\text { work deadlines }\end{array}$ \\
\hline
\end{tabular}

Decisions related to environmental protection in the course of construction and installation works are regulated in Belarus by project documentation - the Construction Organization Project and production documentation - the Work Production Project. These solutions include land reclamation, prevention of loss of natural resources, prevention or treatment of harmful emissions into the soil, reservoirs, and atmosphere, and are reflected in the explanatory notes of these organizational and technological documents and in construction master plans.

It is necessary that environmental protection measures are not just reflected in the project documentation, but also implemented in practice, which is not always the case. Thus, according to the Department of construction control and supervision of the State Committee for standardization of the Republic of Belarus, in 2019, 69\% of the inspected construction sites did not meet the established requirements for their maintenance. Construction work began without prior arrangement of the construction site, without installing fences, areas for washing the wheels of vehicles, containers for separate waste collection; untimely removal of construction debris was carried out.

Responsibility for the implementation of measures for environmental protection at the production stage of the work lies on all of the major participants of investment-construction process: the customer (the developer), the project Manager, the technical supervision of the customer, General contractor, and representatives of the project organization. 
Consideration of the stages of investment and construction activity reflects the complexity of the impact on the environment. Unfortunately, the negative impact is not reduced to the desired level. Each previous stage has an impact on the next one. Raw materials affect the environmental friendliness of building materials, the choice of material affects the environmental friendliness of finished construction objects, the quality of materials and construction affects the amount of waste generated.

In recent years the legislation of the Republic of Belarus on environmental impact issues has been significantly improved, and control over the creation of construction projects has been strengthened.

\section{Legal assessment of environmental construction in the Republic of Belarus}

Regardless of types and goals of activities, the state program "Environmental protection and sustainable use of natural resources" for 2016-2020 has been formed. Under the program "the effectiveness of conservation measures significantly increased, providing positive trends in the environment controlled parameters of pollution and has helped to promote the use of natural resources".

Environmental safety in the construction sector is regulated by:

a) The law of the Republic of Belarus of 05.07.2004 No. 300-3 "On architectural, urban planning and construction activities in the Republic of Belarus",

b) The law of the Republic of Belarus of 18.07.2016 No. 399-3 "On state environmental expertise, strategic environmental assessment and environmental impact assessment",

c) The law of the Republic of Belarus of 26.11.1992 No. 1982-XII "On environmental protection",

d) "Regulations on the procedure for commissioning construction projects", approved by resolution of the Council of Ministers of the Republic of Belarus dated 06.06.2011 No. 716,

e) Regulations on the procedure and conditions for conducting state energy efficiency expertise, approved by resolution of the Council of Ministers of the Republic of Belarus No. 216 of 18.03.2016,

f) Resolution of the Council of Ministers of the Republic of Belarus 19.01.2017 N 47 "Regulations on the procedure for conducting an environmental impact assessment, requirements for the composition of an environmental impact assessment report, requirements for specialists performing an environmental impact assessment",

g) Technical code 17.11-10-2014 "environmental protection and nature management. Waste. Rules for handling construction waste".

In the world ranking on the environmental performance index, the Republic of Belarus improved its position and rose from 73rd place in 2005 to 32nd place in 2014. But in 2018 it was ranked 44th. Indicators of the state of the environment and the viability of the ecosystem have decreased. A number of shortcomings that have affected the decline in these indicators can also be noted in the construction sector.

\section{Distribution of environment protection functions between divisions of organizations participating in the investment and construction cycle}

Development and distribution of special functions within businesses' divisions can ensure managerial functions to get developed, which increases environmental safety of participants of investment-construction cycle (Table 5). 
Effectiveness of implementing distributed functions will depend on the quality of organizational structure of an enterprise, which also becomes a basis for sustainable development of organizations participating in the investment and construction cycle $[16,17]$.

Table 5. Distribution of environment protection functions in an organization.

\begin{tabular}{|c|c|}
\hline Name of division & Environment protection functions \\
\hline Environmental service & $\begin{array}{l}\text { Providing control and coordination work within environment } \\
\text { protection activities of the construction site. }\end{array}$ \\
\hline Production department & $\begin{array}{l}\text { Setting and solving tasks related to preventing and minimizing a } \\
\text { negative impact of the production activity of the project (participant } \\
\text { enterprise) on the environment. }\end{array}$ \\
\hline Logistics service & $\begin{array}{l}\text { Supply of environmentally friendly materials (causing minimal } \\
\text { damage to the environment during transportation, storage, use and } \\
\text { recycling) for the production process. }\end{array}$ \\
\hline Marketing service & $\begin{array}{l}\text { Ensuring that services are clean, safe, and efficient to meet the needs of } \\
\text { consumers. Creating a favorable image of the enterprise (project) by } \\
\text { forming communications with contact audiences. }\end{array}$ \\
\hline Financial department & $\begin{array}{l}\text { Financial support for implementing environmental protection } \\
\text { measures, projects, and contracts. }\end{array}$ \\
\hline $\begin{array}{l}\text { Planning and economic } \\
\text { department }\end{array}$ & $\begin{array}{l}\text { Creating new and improving existing services for water supply, } \\
\text { sanitation and technological processes in order to ensure their } \\
\text { environmental safety. Planning of current and capital environmental } \\
\text { expenditures. Analysis of economic efficiency of environmental } \\
\text { projects and activities. }\end{array}$ \\
\hline Accounting & $\begin{array}{l}\text { Taking into account actual environmental costs and benefits. Providing } \\
\text { financial information to the environmental service. }\end{array}$ \\
\hline Personnel department & $\begin{array}{l}\text { Preparation of employees of the enterprise (operating organization) to } \\
\text { perform environmental tasks at their workplaces; formation of their } \\
\text { environmental thinking. }\end{array}$ \\
\hline $\begin{array}{l}\text { Department of } \\
\text { occupational health and } \\
\text { safety }\end{array}$ & $\begin{array}{l}\text { Prevention of occupational diseases caused by adverse environmental } \\
\text { factors }\end{array}$ \\
\hline $\begin{array}{l}\text { Quality control } \\
\text { department }\end{array}$ & $\begin{array}{l}\text { Ensuring high quality of service while taking into account both } \\
\text { technical and environmental aspects. }\end{array}$ \\
\hline
\end{tabular}

\section{Conclusions}

1. Creating (changing) real estate objects inevitably has a negative impact on the environment.

2. The impact is uneven, there are losses which are specific for each stage.

3. A preliminary analysis allows for obtaining information and assessing risks.

4. Legislative framework contributes to the development of environmental safety of projects of investment and construction processes.

5. In order to improve legislation, it is necessary to perform monitoring and analysis functions.

6. To improve eco-efficiency it is necessary to introduce ecological management in activity of participants of investment-construction cycle.

7. Competent development and distribution of environment protection functions between the divisions of enterprises participating in the investment and construction cycle will help to achieve an increase in environmental safety.

8. This type of activity can provide necessary results only if all the functions of environmental management are constantly performed by participants in investment and construction activities. 
9. Creating an environmentally safe construction project is a complex process that covers all stages of its life cycle. At the stage of concept development and design, the theoretical level of environmental safety of the project is laid. During the construction process, the actual environmental safety of the project is ensured. After the project comissioning, it must be maintained at the required level by a proper organization of operation.

\section{References}

1.C. Llatas, B. Soust-Verdaguer, A. Passer, Building and Environment 182, 107164 (2020)

2. S. Seyis, Building and Environment 173, 106703 (2020)

3.R. Santos, A.A. Costa, J.D. Silvestre, T. Vandenbergh, L. Pyl, Building and Environment 169, 106568 (2020)

4.M. Najjar, K. Figueiredo, A.W.A. Hammad, A. Haddad, Applied Energy 250, pp. 1366-1382 (2019)

5. T.D. Johansson, W. Lu, J. Schade, T. Olofsson, Energy and Buildings 128, pp. 592-604 (2016)

6.C. Cavalliere, G. Habert, G.R. Dell'Osso, A. Hollberg, Journal of Cleaner Production 211, pp. 941-952 (2019)

7.V.W.Y. Tam, K.N. Le, Sustainable construction technologies (Butterworth-Heinemann, 2019)

8.D.T. Doan, A. Ghaffarianhoseini, N. Naismith, T. Zhang, A. Ghaffarianhoseini, J. Tookey, Building and Environment 123, pp. 243-260 (2017)

9.K. Galal, S. Alkass, Building and Environment 80, pp. 61-70 (2014)

10. A. Fuertes, M. Casals, M. Gangolells, N. Forcada, M. Macarulla, X. Roca, Journal of Cleaner Production 52, pp. 425-437 (2013)

11. J. Hong, H. Kang, S. Yung, S. Sung, T. Hong, H.S. Park, D.-E. Lee, Building and Environment 170, 106636 (2020)

12. H. Bon-Gang, Performance and improvement of green construction projects (Butterworth-Heinemann, 2018)

13. A.N. Kochurko, L.G. Sryvkina, Vestnik BSTU 1, pp. 100-106 (2019)

14. N.V. Mikhailova, E.I. Kisel, Vestnik BSTU 3, pp. 61-65 (2019)

15. A. Barylka, Inżynieria Bezpieczeństwa Obiektów Antropogenicznych 1-2 (2019)

16. O.A. Vysotski, Vestnik BSTU 3, pp. 2-5 (2016)

17. O.A. Vysotski, I.M. Garchuk, N.S. Danilova, V.F. Medvedeva, Basics of sustainable development of a production organization (Pravo i ekonomika, Minsk, 2015) 